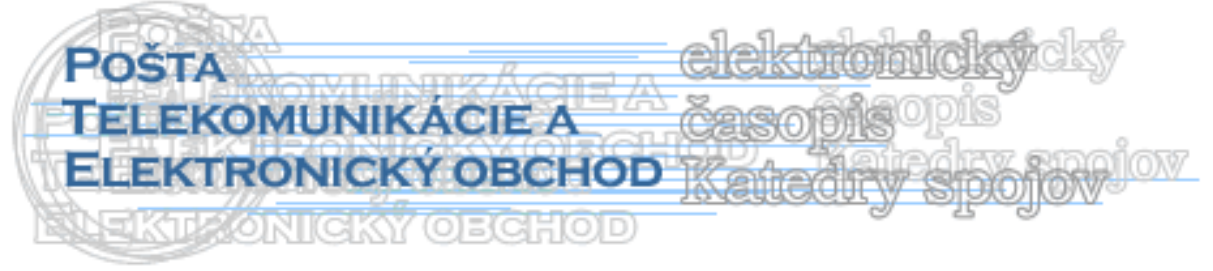

\title{
ŠPECIALIZÁCIA DORUČOVACÍCH RAJÓNOV PODL'A DORUČOVANÝCH ZÁSIELOK
}

\author{
Pavol Dydňanský*, Radovan Madleňák ${ }^{\dagger}$
}

\section{1 Úvod}

Optimalizáciu doručovania $\mathrm{v}$ poštovom podniku je možné realizovat' rôznymi metódami a postupmi, prechádza prierezovo všetkými činnostami doručovania, zmenou technológie doručovania, špecializáciou doručovacích rajónov, zmenou zaradenia doručovatel'ov, zmenou pracovných úväzkov a v neposlednom rade doručovacou pochôdzkou Doručovací rajón, t.j. čast' poštového obvodu v ktorej doručuje jeden doručovatel'. [1]

\section{Analýza súčasného stavu vybranej dodávacej pošty}

Zmenu v doručovaní predchádza dôkladná analýza súčasného stavu. V prvom rade je potrebné stanovit' objekt optimalizácie, t.j. poštu ako celok, prípadne jej jednotlivé doručovacie rajóny, doručovatel'ov. Analýza súčasného a minulého stavu nám pomáha spoznat' aktuálny stav doručovania, odkrýva problémy, poukazuje na hrozby a stanovuje potencionálne príležitosti zlepšenia.

V našom prípade sa jedná o modelovú dodávaciu poštu s nasledujúcimi parametrami:

- dodávacia pošta $\mathrm{v}$ mestskej časti,

- počet listových doručovatel'ov 12 (DR č. 1 až 12),

- zloženie materiálu na doručovanie:

- listové zásielky, listové zásielky na dobierku, doporučené zásielky, reklamne adresované zásielky, úradné zásielky, periodické zásielky, poštové poukazy, dôchodky a dávky, SIPO, letáky,

- počet doručovatel'ov tlače a časopisov 3 (DR č. 1 až 3),

- zloženie materiálu na doručovanie:

- noviny, časopisy.

\section{Stanovenie ciel'ov}

Každou optimalizáciou stanovujeme hlavný ciel' ako aj čiastkové ciele. Jedná sa o zásadnú zmenu organizácie práce $\mathrm{v}$ doručovaní. Primárnym ciel’om je udržanie, resp. zníženie celkových nákladov na doručovanie. [3] Stanovenie ciel’ov má za úlohu zlepšenie kvality doručovania, resp. zefektívnenie procesov doručovania:

- zníženie celkových nákladov na doručovanie,

\footnotetext{
* Ing. Pavol Dydňanský, Slovenská pošta, a.s., Thurzová 1, 04221 Košice, Slovenská republika, tel. č.: +421/55/6813 235, e-mail: dydnansky.pavol@slposta.sk

† doc. Ing. Radovan Madleňák, PhD., Žilinská univerzita v Žiline, Fakulta Prevádzky a ekonomiky dopravy a spojov, Katedra spojov, Univerzitná 1, 01026 Žilina, tel. č.: 041/513 3129, fax: 041/5655 615, e-mail: radovan.madlenak@fpedas.uniza.sk
} 
- zvýšenie efektivity doručovania,

- minimalizovanie rizík bezpečnosti na doručovacej pochôdzke,

- skrátenie doručovacej pochôdzky, atd'. [2]

Definované ciele optimalizácie doručovania budeme realizovat' prostredníctvom zmeny organizácie práce, na základe špecializácie doručovacej služby, podl’a druhu zásielky, služby a adresáta.

\section{Riešenie optimalizácie špecializáciou doručovacích rajónov}

Riešenie optimalizácie špecializáciou doručovacích rajónov podl’a doručovaných zásielok, plánujeme spôsobom, že budú vytvorení tzv. „bielych a červených“ doručovatel'ov. „Červení“ doručovatelia budú doručovat' zapísaný materiál, resp. materiál, ktorý sa doručuje naproti podpisu adresáta. „Bieli“ doručovatelia budú doručovat' nezapísaný materiál, ktorý nie je potrebné doručovat' oproti podpisu adresáta a teda je doručovaný do domových listových schránok podl'a adresy adresáta.

Takéto rozdelenie je z dôvodu, aby „biely“ doručovatel' nemusel vynášat' materiál vo viacpodlažných bytových panelákoch a doručoval tento materiál len do domových listových schránok bez podpisu adresáta. Naopak „červený“ doručovatel' by sa pohyboval s menším, resp. minimálnym materiálom na väčšom území.

$\mathrm{V}$ rámci riešenia je požiadavka, aby sa „,bieli doručovatelia“ nevracali spät’ na dodávaciu poštu s materiálom, ktorí nebolo možné doručit’ do schránok adresátom.

Riešením je vytvorenie takých rajónov u „bielych“ doručovatel’ov, aby po ukončení pochôdzky zanechali nedoručený materiál kumulovane za rajóny na jednom odovzdacom mieste, napr. zanechat' na prízemí bytovky v špeciálnej schránke. Tieto schránky by po ukončení pochôdzky vyberali „červení“ doručovatelia.

Pôvodný stav doručovatel'ov je 12 a 3 doručovatelia časopisov a predplatného tlače, čo je spolu 15 kmeňových doručovatel'ov a rovnaký počet 15 doručovacích rajónov.

Doručovacie rajóny pre „bielych“ doručovatel'ov navrhujeme 15 (doručovatelia so skráteným pracovných úväzkom, resp. s polovičným). Pre červených doručovatel'ov 6 (doručovatelia interní, kmeňoví s trvalým pracovným pomerom a plným úväzkom). Kmeňových doručovatel'ov bude len 6 , čo výrazne zníži náklady na zamestnancov aj napriek tomu, že externých doručovatel'ov - brigádnikov bude 15. Z navrhovaného riešenia optimalizácie doručovania vyplýva, že dochádza k decentralizácií doručovania a k zvýšeniu efektivity, nakol'ko sa vytvoria špecializované doručovacie rajóny, ktorým bude venovaná zvýšená pozornost' zo strany poštového podniku. Popis špecializácie doručovacích rajónov, tzv. „bieli a červení“ doručovatel’ov je definovaný nasledovne:

\section{BIELI DORUČOVATELIA}

- pracovná doba: pondelok až piatok: skrátené, polovičné pracovné úväzky,

- externí zamestnanci - brigádnici, študenti, živnostníci,

- doručovacie rajóny č. B1, B2, B3 až B15,

- doručovatelia zabezpečujú doručovanie:

- listové zásielky,

- SIPO,

- Letáky,

- tlač a časopisy v predplatnom,

- obyčajné listové zásielky,

- nedoručené obyčajné listové zásielky, vloží doručovatel do označenej poštovej schránky nachádzajúcej sa na určenom mieste na konci doručovacej pochôdzky. 


\section{ČERVENÍ DORUČOVATELIA}

- pracovná doba: pondelok až piatok: plný pracovný úväzok,

- interní, kmeňoví zamestnanci, pracovná zmluva, trvalý pracovný pomer

- doručovacie rajóny č. C1, C2, C3, C4, C5, C6,

- doručovatelia zabezpečujú doručovanie:

- listové zásielky oproti podpisu,

- upomienky SIPO,

- dávky národný okruh a okresný okruh,

- obyčajné listové zásielky,

- vyberie nedoručené obyčajné listové zásielky, ktoré vložil biely doručovatel' do označenej poštovej schránky nachádzajúcej sa na určenom mieste na konci doručovacej pochôdzky a zanesie na poštu.

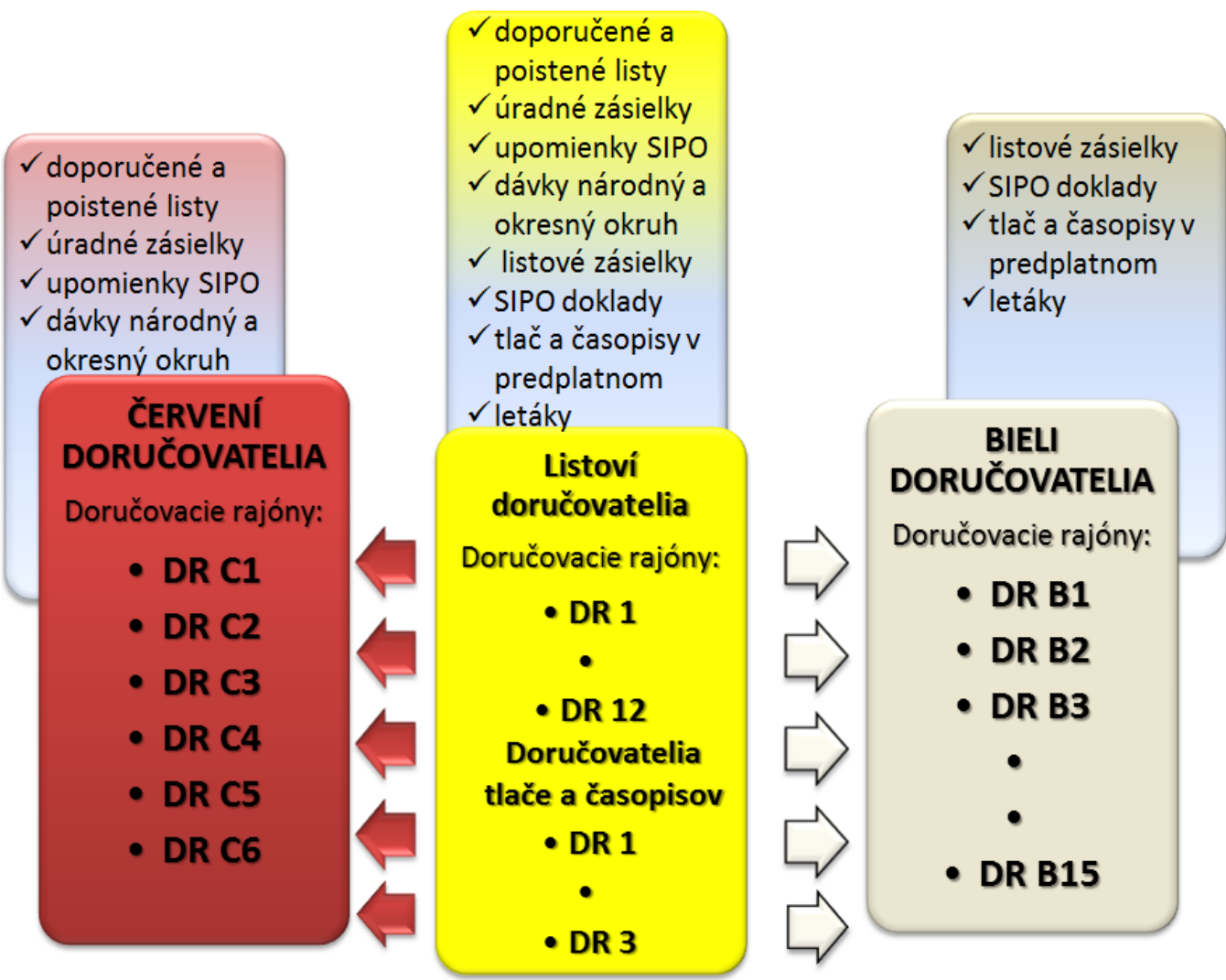

Obrázok 1. Schéma znázorňujúca riešenie optimalizácie špecializáciou doručovacích rajónov, tzv. „bieli a červení" doručovatelia

\section{Záver}

Vo všeobecnosti aj napriek problémom s akceptovaním zmien, je potrebné hl'adat' optimálne a zákaznícky výhodnejšie riešenia. Optimalizáciou doručovania poštový podnik navrhuje nový systém v oblasti zabezpečovania dodávacej služby. Navrhovaným riešením optimalizácie špecializáciou doručovacích rajónov dochádza $\mathrm{k}$ decentralizácií doručovania a $\mathrm{k}$ zvýšeniu efektivity, nakol'ko sa vytvoria špecializované doručovacie rajóny, ktorým bude venovaná zvýšená pozornost' zo strany poštového podniku. Takéto riešenia by poštovému podniku umožnili zefektívnenie doručovania. 
[1] Metodické vysvetlivky s štátnemu štatistickému zist'ovaniu poštového regulačného úradu v odvetví pošty. 2012. [online]. Žilina : Poštový regulačný úrad, 2012. [cit. 2012-11-20]. Dostupné na internete: <http://portal.statistics.sk/files/Sekcie/sek_200/Vzory_formularov/rok_2012/f_popru_mv _12.pdf $>$.

[2] Technologická pripravenost' poskytovatel’a univerzálnej poštovej služby na liberalizáciu trhu poštových služieb a rozvoj informačno - technickej infraštruktúry. [online]. [cit. 2012-11-20]

Dostupné na internete: <http://www.telecom.gov.sk/pk/050337/priloha_13.htm>.

[3] Madleňáková, L.: Optimalizácia dodávacej služby zriad’ovaním dodávacích centier. In: Diagnostika podniku, controlling a logistika: V. medzinárodná vedecká konferencia : zborník prednášok a príspevkov : 21.-22. apríl 2010, Žilina. - Žilina: Žilinská univerzita, 2010. - ISBN 978-80-554-0175-1. - S. 211-219.

\section{Grantová podpora}

- KEGA-053ŽU-4/2013 - Skvalitnenie a prepojenie kl'účových predmetov študijného programu Elektronický obchod a manažment

- IMTS 26110230083 - Kvalita vzdelávania a rozvoj l’udských zdrojov ako piliere vedomostnej spoločnosti na Fakulte PEDAS Žilinskej univerzity v Žiline

- VEGA 1/0421/12 - Modelovanie difúzie znalostí v podnikových hodnotových retazcoch 